\title{
Marihuana - zlouporaba i medicinska uporaba
}

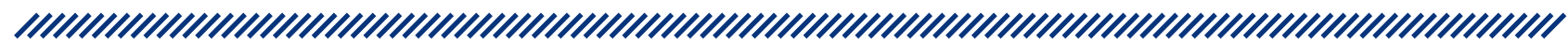

1 Marija Markus Klarić

2 Dubravko Klarić

3 Ognjen Brborović

4 Krunoslav Capak

1 Vlada RH, Vladin ured

2 Ministarstvo zdravstva RH, Povjerenstvo za medicinsku uporabu kanabisa

3 Medicinski fakultet Sveučilišta u Zagrebu, Katedra za socijalnu medicinu i organizaciju zdravstvene zaštite

4 Hrvatski zavod za javno zdravstvo, Zagreb

\section{Sažetak}

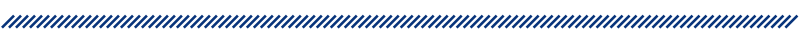

Indijska konoplja (lat. Cannabis sativa L., podvrsta indijska) prati čovjeka od pradavnih vremena pa sve do danas. Prepoznati učinci indijske konoplje kao psihoaktivnog sredstva (glavni sastojak THC delta-9-tetrahidrokanabinol) doveli su do različitih oblika uporabe, ali i kao lijeka u medicinske svrhe. Tehnološki napredak, brojna istraživanja, dovela su do otkrića velikog broja drugih sastojaka (CBD kanabidiol - kanabinoidi) koje sadržava indijska konoplja, a nisu psihoaktivni, međutim našli su svoju primjenu u medicinskoj terapiji. Samom uporabom nužno se pojavila i zlouporaba. Marihuana je danas, iako samo kao jedan od produkata, postala u svakodnevnoj komunikaciji sinonim za indijsku konoplju. Na nelegalnim je tržištima najraširenija droga, kako u ponudi tako i potražnji (produkti hašiš, ulje hašiša, razne mješavine i oblici produkata indijske konoplje nisu toliko rasprostranjeni kao marihuana). Proizvodnju, prenošenje - krijumčarenje, preprodaju i konzumaciju trebalo je staviti pod državni nadzor, odnosno u zakonske okvire, što je i učinjeno, ali uz stalne promjene. To se nije moglo i ne može se regulirati samo u nacionalnim okvirima, već prema konvencijama na širokoj međunarodnoj sceni, uz učešće međunarodnih organizacija, poglavito UN-a. Ipak usklađenost nacionalnih zakonskih okvira s međunarodnima ostavlja prostor za današnje trendove u smislu dekriminalizacije, depenalizacije i legalizacije, što je isto tako dio kulturoloških, bihevioralnih, socioloških, ali i političkih pristupa prema određivanju uporabe i zlouporabe. Granicu između nelegalne odnosno nezakonite primjene ponekad će biti teško odrediti, ali svakako u tom smislu potreban je znanstveni i empirijski multidisciplinarni pristup, razumijevanje, ali i donošenje odgovarajućih odluka.

Ključne riječi: marihuana, konoplja, zlouporaba, medicinska uporaba

Datum primitka: 15.10.2019.

Datum prihvaćanja: 15.01.2020.

https://doi.org/10.24141/1/6/1/13

Adresa za dopisivanje:

Marija Markus Klarić

Gornji Bukovac 3, odvojak 15, 10000 Zagreb, Hrvatska

E-mail:marijamrks@gmail.com

T: +385917811160 


\section{Uvod}

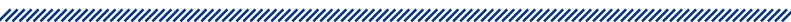

Droga je počela pratiti čovjeka od pradavnih vremena, kao medikament za ublažavanje boli, smirenje ili druge zdravstvene tegobe, ali i kao prateće sredstvo u vjerskim obredima, ceremonijama, posebnim prigodama, mijenjajući čovjeku psihofizičko ponašanje, djelomice ili u cijelosti. Tako se uz opijum (prirodni izvor opijumski mak - lat. Papaver somniferum), lišće koke i pojedine vrste gljiva spominje i indijska konoplja (lat. Cannabis sativa L., podvrsta indijska) - čije se sušeno lišće pojavljuje kao marihuana.

Podaci koji se odnose na razne oblike uporabe proizvoda konoplje - kanabisa također sežu u daleku prošlost. Iz arheoloških se podataka vidi da je ta biljka služila u različite svrhe već prije najmanje 6000 godina (u Kini se 2700. pr. Kr. spominje njezin opširan opis, vladar Shen Nung). Skiti, nomadski narod koji je živio u području Volge od 700. - 300. g. pr. Kr., navodno su uzgajali i konzumirali kanabis, a Herodot, grčki pisac iz doba stare Grčke (oko 480. pr. Kr.) piše u svojim djelima da su je baš Skiti uporabljivali pri pogrebnim obredima, paleći lišće i udišući dimove. Indijske Vede (Svete knjige Brahmana pisane sanskrtom, vrijeme pisanja nepoznato, no pretpostavlja se od 1400 . pr. Kr.) spominju farmakološke osobitosti indijske konoplje (Klarić 2016). U Europu su indijsku konoplju donijeli Mauri, sjevernoafrička plemena, početkom 8. stoljeća, ali je opširnije opisana i ispitana tek za vrijeme Napoleonove okupacije Egipta.

Povijesno gledano, razni oblici uporabe imali su i svoje negativne učinke, koji su kako u prošlim tako i današnjim vremenima podrazumijevali i zlouporabu. Kao i sve druge droge, tako su i produkti indijske konoplje (marihuana, hašiš i hašišovo ulje), uz uporabu u ljekovite, farmakološke, odnosno medicinske svrhe, sve više počeli biti predmetom ljudske zlouporabe. Upravo zbog takvih negativnih učinaka po konzumente stvorila se potreba za zakonskim reguliranjem proizvodnje, prodaje i konačno konzumacije. Jedan od važnih razloga za takvu društvenu inicijativu bili su štetni i rizični učinci, kao uzročno-posljedična veza s konzumacijom, usprkos medicinsko-farmakološkoj opravdanosti pozitivnih terapijskih učinaka kod nekih bolesti. Tako je donošenjem međunarodnih konvencija (Konvencija o opojnim drogama iz 1961.) ${ }^{1}$

1 Potrebnost učinkovitije zakonske regulacije zlouporabe prepoznala je međunarodna je zajednica, pod okriljem Ujedinjenih na- i indijska konoplja (lat. Cannabis sativa L.) stavljena kao droga pod režim međunarodne kontrole.

Bez obzira na zakonsku kažnjivost same zlouporabe droge u bilo kojem smislu, kako kroz ponudu tako i potražnju, gledajući drogu kao robu, u prošlosti i današnjim trendovima, a tako će biti i u budućnosti, u ilegalnoj je proizvodnji, krijumčarenju i preprodaji „roba broj 1". Prema rasprostranjenosti zlouporabe upravo je marihuana najprisutnija, kako na nacionalnoj tako i međunarodnoj narkosceni.

O uporabi indijske konoplje u farmakološkom smislu na području Hrvatske podaci datiraju s početka 20. stoljeća, kada se spominje u prvoj hrvatskoj farmakopeji. ${ }^{2}$ Posljednjih nekoliko desetljeća uporaba marihuane $u$ medicinske svrhe sve je prisutnija kao predmet medicinsko-farmakoloških istraživanja i kliničkih ispitivanja. Pozitivni terapijski učinci uporabe u medicinske svrhe dokazano su prisutni kod određenih bolesti. Sama biološka struktura indijske konoplje s nizom bioaktivnih sastojaka sigurno će omogućiti terapijsku uporabu kod još više bolesti nego do sada, kada postoji mogućnost ublažavanja tegoba kod multiple skleroze, karcinoma, epilepsije i AIDS-a.

Marihuana kao najrasprostranjeniji produkt indijske konoplje ima važno mjesto u svakodnevnom životu, bez obzira na to je li riječ o zakonski predviđenoj uporabi ili zlouporabi. Stručne i znanstvene spoznaje, informiranost društva, preventivne aktivnosti, strategije, uz nužno prateći pristup državnog nadzora važan su čimbenik i regulator za pozitivnu i korisnu uporabu, ali svakako za suzbijanje ilegalne proizvodnje, krijumčarenja, prodaje i konzumacije.

roda. Tako je 20. ožujka 1961. donesena Jedinstvena konvencija o opojnim drogama (tzv. Njujorška konvencija). Dijalektičnost same zlouporabe uvjetovala je potrebu nadopunjavanja spomenute Konvencije, pa je s time u vezi već 25. ožujka 1972. u Ženevi donesen Protokol o izmjenama i dopunama Jedinstvene konvencije o opojnim drogama iz 1961. godine. Zatim je iz istih razloga u Beču 21. veljače 1971. donesena Konvencija o psihotropnim supstancijama (tzv. Bečka konvencija), kojom su supstancije, zbog sve masovnije zlouporabe s izrazito štetnim posljedicama, stavljene pod međunarodni nadzor. Nadalje, važan korak UN-a u zakonskom kontekstu bilo je donošenje Konvencije Ujedinjenih naroda protiv nezakonitog prometa drogama i psihotropnim supstancijama u Beču 20. prosinca 1988. Tom se konvencijom pod međunarodni nadzor stavljaju i supstancije koje se primjenjuju u proizvodnji droga i psihotropnih supstancija

2 Hrvatsko-slavonski ljetopis, 1901. str. 172 


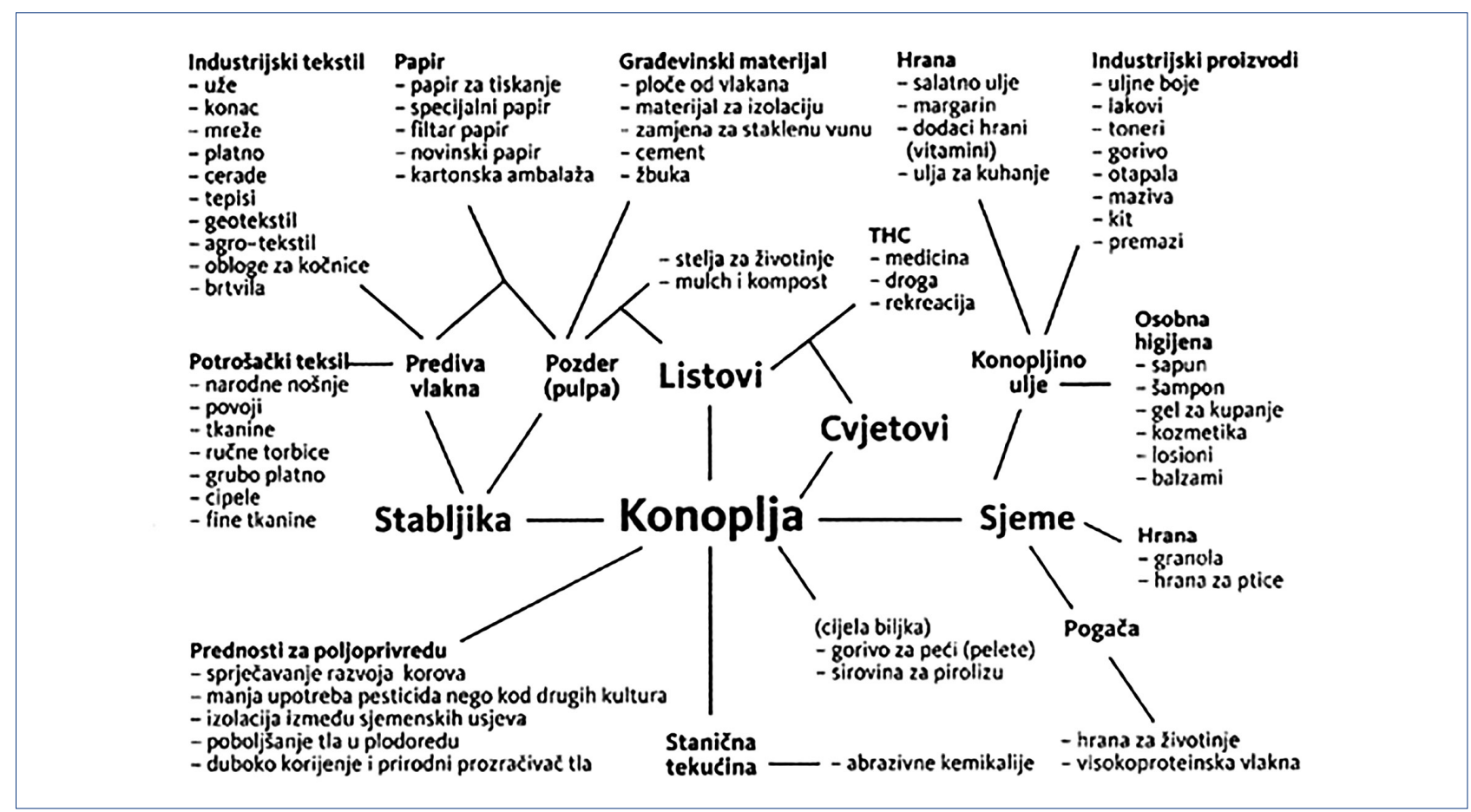

Slika 1. Uporaba konoplje

Izvor: http://blog.agrivi.com/hr/post/povratak-industrijske-konoplje-za-opstanak-covjecanstva

\section{Konoplja - morfologija}

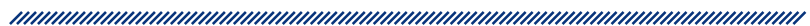

Već je u uvodnom dijelu spomenuto kako je konoplja (lat. Cannabis) od pradavnih vremena poznata čovjeku. Treba naglasiti da je kao biljka imala svoju primjenu za proizvodnju vlakana, što bi se moglo podrazumijevati komercijalnom uporabom (građevinarstvo, tekstilna proizvodnja, kozmetika, prehrambena, građevinarstvo itd., prema nekim pokazateljima, više od 20000 raznih proizvoda i načina primjene), no isto tako rano su prepoznata psihoaktivna svojstva koje sadrži u jednoj od svojih podvrsta, tako da je primjena postala znatno šira, što se zadržalo do današnjih dana. ${ }^{3}$

S polazišta botanike, konoplja je jednogodišnja dvodomna (muški cvjetovi i ženski cvjetovi na zasebnim, odvojenim biljkama) zeljasta biljka, a stabljika i listovi pre-

3 Na području Hrvatske i u široj regiji konoplja se uzgajala upravo radi vlakana i u postupku proizvodnje tekstilne sirovine miješala se s lanom pa je tako dobivena čvrsta, kvalitetna tkanina. Takva proizvodnja bila je vrlo zastupljena od početka dvadesetog stoljeća, ali i ranije. U drugoj polovici dvadesetog stoljeća spomenuta proizvodnja postala je rijetka, tako da se sadnja u komercijalne svrhe svodila uglavnom na sjemenke kao hranu za ptice kriveni su kratkim dlačicama te se svrstava u istoimenu porodicu konoplji (lat. Cannabaceae). Tvari koje imaju halucinogena svojstva biljka izlučuje u „dlačicama” koje se u većim nakupinama pojavljuju na svim dijelovima cvjetova ženskih biljki. Ovisno o vrsti konoplje, visina stabljika varira od nekoliko desetaka centimetara do šest metara. Visina stabljike ovisit će o području uzgoja (na sjeveru je stabljika niska, a na jugu visoka), tipu tla, agrotehnici i uvjetima uzgoja. Stabljika muških biljaka nešto je viša od stabljike ženskih biljaka. Od ukupne mase biljke obuhvaća oko $65 \%$. Debljina iznosi oko 6 do $8 \mathrm{~mm}$, a sjemenska konoplja ima stabljiku debelu više centimetara. ${ }^{4}$

Od botaničkih podjela najzastupljenija je ona koja konoplju dijeli na tri vrste, i to:

1. industrijska (lat. Cannabis sativa - uporabljuje se i pod nazivom sjetvena, u botaničkom je smislu raširenija od ostalih vrsta)

4 Iz iskustava kriminalističke prakse 80-ih godina prošlog stoljeća, koja su se odnosila na sadnju u smislu zlouporabe na širem području Zagreba, stabljike biljki konoplje znale su imati debljinu i više od pet centimetara. U jednom slučaju sadnje konoplje iza septičke jame na periferiji Zagreba, od dvije biljke čije su stabljike bile debljine šest centimetara i visine više od tri metra, ubrana je količina od 10 kilograma listova, a koncentracija THC-a u njima bila je $5 \%$. Zanimljivo je kako je sjeme bilo legalno kupljeno u trgovini sjemena kao hrana za ptice. 
2. indijska konoplja (lat. Cannabis indica - sadrži visoki postotak psihoaktivne tvari THC; uz medicinsku primjenu, pojavljuje se kao najučestalija droga na ilegalnim tržištima širom svijeta)

3. divlja (ruderalna) konoplja (lat. Cannabis ruderalis). Navedena podjela u znanstvenoj i stručnoj literaturi najviše se spominje, no dio botaničke struke zastupa i drugu podjelu, prema kojoj konoplju dijeli samo na Cannabis sativu s dvije podvrste: sativa i indijska.

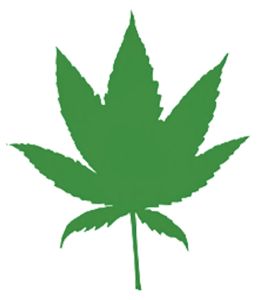

\section{indica}

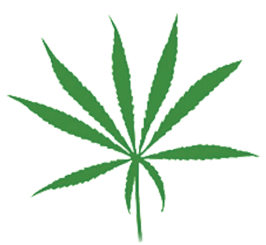

\section{sativa}

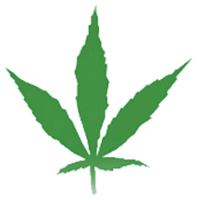

ruderalis

Slika 2. Vidljive razlike $u$ obliku listova pojedinih vrsta konoplje

Izvor: www.nomadicmedhunter.wordpress.com

U biološkoj strukturi konoplje postoji više od 400 raznih strukturalno prepoznatljivih sastojaka. Među sastojcima se nalazi velik broj kanabinoida ${ }^{5}$ (ovisno o uzgoju i vrsti konoplje, broj varira od 60 do 110). U svijetu su aktualna istraživanja biljki (Echinacea, kakaovac, Radula marginata...) koje, kao i konoplja, sadrže pojedine kanabinoide, no struktura im je drugačija, uz slično djelovanje i učinke kao kod konoplje.

Jedan od najvažnijih kanabinoida koji se nalaze u konoplji jest tetrahidrokanbinol (THC). Kanabinoid (-)3,4-trans-delta-1-tetrahidrokanabinol u stručnoj i

5 Kanabinoidi su aktivni sastojci konoplje. Iz biljke Cannabis sativa L. najpoznatiji su kanabidiol (CBD), kanabidivarin (CBDV), delta9-tetrahidrokanabinol (delta-9-THC) i kanabigerol (CBG). Unutar biljke kanabinoidi se sintetiziraju i akumuliraju u obliku karboksilnih (organskih) kiselina (CBDA, THCA, CBCA i CBGA), koje se zatim pretvaraju u neutralne oblike dekarboksilacijom znanstvenoj komunikaciji pojavljuje se i pod nazivima delta-1-THC, delta 9-THC, odnosno samo THC. Jaka je psihoaktivna tvar i u biljci se nalazi u velikim količinama. ${ }^{6}$ (THC obično čini 1 do $5 \%$ mase biljke. Koncentracija uobičajeno varira od 2 do $7 \%$, ovisno o samoj biljci, njezinu dijelu, vrsti, načinu uzgoja i vremenu ubiranja listova.) Današnji trendovi ilegalne sadnje i uzgoja indijske konoplje pokazuju sve veću učestalost unutarnjih plantažnih sadnji (engl. indoor). Vrste biljki su različite (u kriminalnom žargonu spominju se pod raznim nazivima kao sensimila, besjemena, kolumbijska...), nerijetko su tu vrste koje su genetički modificirane te daju jaku koncentraciju THC-a, i veću od $30 \%$. (Ako je koncentracija THC-a manja od 0,2 \%, biljka odnosno produkt ne smatra se drogom.)

Tetrahidrokanabinol se u biljci ne nalazi u svojem aktivnom obliku, već u obliku tetrahidrokanabinolinske kiseline (THCA). Tetrahidrokanabinolinska kiselina u reakciji dekarboksilacije, koju katalizira toplina, prelazi u tetrahidrokanabinol. To znači da, ako osoba konzumira sirovu marihuanu, odnosno marihuanu koja nije toplinski obrađena, neće osjetiti njezin psihoaktivni učinak (Gieringer i sur. 2008).

Uz navedeni THC, drugi je važan kanabinoid kanabidiol CBD. Za razliku od THC-a, CBD nema psihoaktivni učinak. Oba kanabinoida pojavljuju se u biljci, djeluju sinergijski i kemijski gledano imaju istu molekularnu strukturu: 21 atom ugljika, 30 atoma vodika i dva atoma kisika. Razlika je u rasporedu atoma, što objašnjava različite utjecaje na organizam konzumenta. Također su kemijski slični endokanabinoidima ljudskog tijela. To im omogućuje interakciju s endogenim kanabinoidnim receptorima. Interakcija utječe na oslobađanje neurotransmitera ${ }^{7}$ u mozgu. Razumijevanje funkcije neurotransmitera kod konzumacije psihoaktivnih sredstava važno je s medicinskog polazišta za stvaranje ovisnosti.

6 Slijedom kriminalističke prakse, prilikom otkrivanja slučajeva ilegalnih sadnji utvrđeno je kako počinitelji kaznenog djela ilegalne proizvodnje nisu odmah ubirali cijelu biljku, već su u ciklusu rasta stabljike kidali listove vrhova biljke, gdje je koncentracija THC-a bila najveća. Ubirali su listove najčešće u podne kad je sunce bilo najjače.

7 Neurotransmiteri (neuro- + lat transmittere - prenijeti; neuroprijenosnici) su kemijski spojevi koji prenose živčane impulse. Oslobađaju se djelovanjem akcijskih potencijala i kalcijevih iona na završecima živčanih vlakanaca, prenoseći podražaj sa živca na glatki mišić, mišić kostura, žlijezdu, srčani mišić ili pak s jednoga neurona na drugi (u središnjem živčanom sustavu). Postoji više od 50 takvih spojeva, među kojima su acetilkolin, katekolamini (adrenalin, noradrenalin, dopamin) i serotonin. Za otkrivanje uloge neurotransmitera posebno su zaslužni nobelovci J. C. Eccles, J. Axelrod i B. Katz. Enciklopedijski članak: neurotransmiteri, online izdanje Hrvatske enciklopedije Leksikografskog zavoda Miroslav Krleža (www.enciklopedija.hr/natuknica.aspx?ID=43565). 


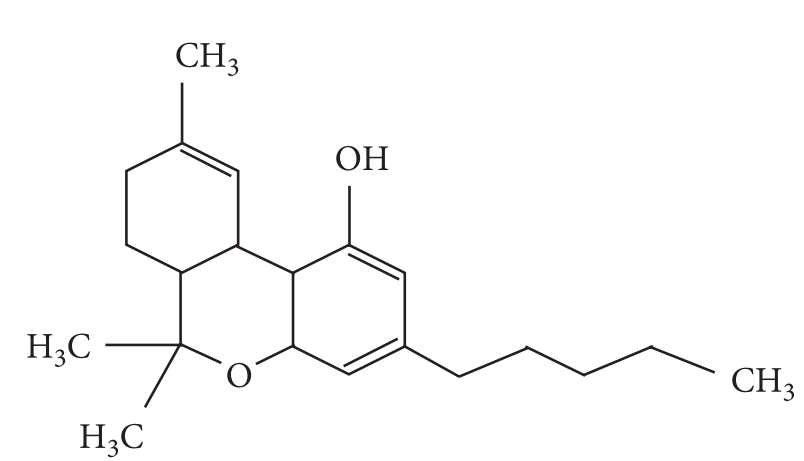

Tetrahydrocannabinol (THC)

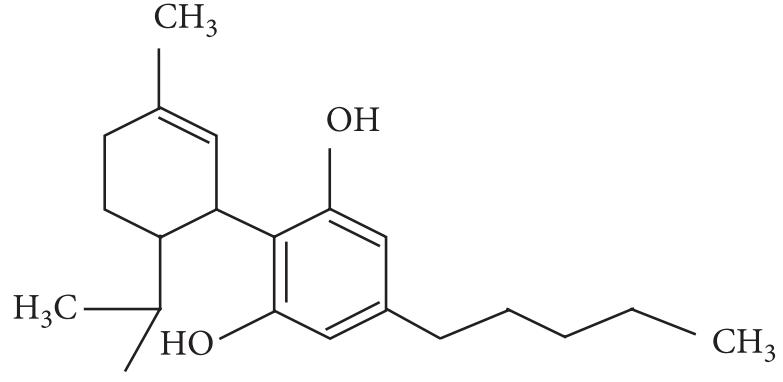

$\mathrm{H}_{3} \mathrm{C}$

Cannabidiol (CBD)

Slika 3. Kemijska molekularna struktura THC-a i CBD-a, gdje je vidljiva sličnost i razlika u rasporedu atoma

Izvor: https//hr.hanf-gesundheit.de

Štetni su učinci THC-a u ljudskom organizmu, u smislu zlouporabe, halucinacije, osjećaj euforije, poremećaji u slušnoj, vidnoj i prostornoj percepciji, dehidracija, poremećaj motorike, omamljenost i crvenilo očiju. Utjecaj je na pluća takav da izaziva promjene slične kao i kod kroničnog pušača duhana - upala grkljana, bronhitis, kronični kašalj. Količine katrana i ugljikova monoksida koju udahne osoba koja puši marihuanu tri su do pet puta veće nego one koju udahne pušač duhana, tako da su izjave kako je marihuana manje štetna od duhana potpuno neutemeljene. Štoviše, zbog posebnog načina pušenja marihuane, kojim se dim puno duže zadržava u plućima te zbog pušenja bez filtra povećava se unošenje svih štetnih tvari u organizam.

Naziv marihuana gotovo je u svakodnevnoj komunikaciji, a moglo bi se reći i u stručnoj, postao drugi naziv za indijsku konoplju. To bi trebalo promatrati poglavito u kontekstu s namjerom sadnje, uzgoja i trošenja. Sigurno je da je krajnji cilj ilegalne sadnje indijske konoplje u današnjim trendovima dobivanje marihuane. $\mathrm{U}$ tom smislu nalazi se i opravdanost poistovjećivanja same indijske konoplje s marihuanom. Kad se govori o ostalim produktima indijske konoplje, hašiš (smola, od crne, tamnosmeđe do svjetlosmeđe boje, karakterističnog sladunjavog mirisa) ${ }^{8} \mathrm{i}$ hašišovo ulje (hašiš se dobi-

8 Hašiš se nakon proizvodnje i formiranja u pogače ili ploče pakirao u platnene vrećice, a danas je najčešće omotan u plastične folije, isto kao i marihuana, kako bi se što duže zadržavala svojstva. Ilegalni proizvođači na ploče utiskuju razna obilježja, primjerice u obliku kaligrafskih crteža, koja simboliziraju kvalitetu i porijeklo. Tako se pojavljuju nazivi „marokanac”, „afgan”, „libanonac” itd., što je prisutno i na današnjoj narkosceni. Koncem osamdesetih na područje Zagreba, radi daljnje distribucije i osobne konzuma- va struganjem s lišća i stabljike, dok se ulje proizvodi otapanjem smole uz razna otapala - eter, aceton, benzol...) imaju znatno jaču koncentraciju od marihuane, od 20 do 50 \% THC-a, ali su isto tako, globalno gledajući, manje zastupljeni u zlouporabi. Hašiš i ulje namijenjeni su isključivo zlouporabi. Razne mješavine marihuane $\mathrm{s}$ drugim tvarima (med, kakao, brašno, drugi biljni produkti) pojavljuju se u nekim područjima svijeta, primjerice na području Indije i Jamajke, pod nazivima charas, bhang i ganja (Kušević 1990). Današnje vrste marihuane prisutne u ilegalnoj proizvodnji postižu visoku koncentraciju THC-a, gotovo izjednačenu, pa čak veću od hašiša i ulja. Što se tiče samih naziva koji se koriste u žargonu zlouporabe, vrlo ih je raznolik i velik broj, a ovise o lokaciji i govornom području. Danas su dosta prisutni anglo-američki nazivi, no i u Hrvatskoj pojedini nazivi u žargonu ovise o regiji (šit, trava, marica, žiža, trava...).

Bez obzira na zakonske pristupe prema bilo kojem obliku manipulacije marihuanom, državni je nadzor nezaobilazan. Današnji tolerantniji, liberalniji stavovi prema rekreativnoj uporabi (zlouporabi) mogu, ako nisu dobro postavljeni i strategijski osmišljeni, imati u raširenosti i štetnosti posljedice za konzumente (i one potencijalne), koje će u budućnosti teško biti popraviti i svesti u gra-

cije, dvojica hrvatskih državljana iz Libanona su prokrijumčarili pet kilograma svjetlosmeđeg hašiša. U tijeku kriminalističkog istraživanja došlo se do podataka da su sami u dolini Beka u Libanonu skupljali smolu, i to na vrlo neobičan način. Skinuli su odjeću i trčali kroz polja indijske konoplje u vrijeme jakog sunca, a na oznojena tijela skupljala se smola. Potom su s tijela strugali smolu i pakirali je u plastične omote. Provedenim forenzičkim vještačenjem zaplijenjenog hašiša utvrđena je koncentracija od $25 \%$ THC-a. 
nice društveno prihvatljivog rizika. Slijedom opisanih danas prisutnih vrsta marihuane koje po svoj jačini, odnosno koncentraciji znatno prelaze prijašnjih 5 do $8 \%$ THC-a, javnost i cjelokupni sustav državnog nadzora mora to imati u vidu. Realno gledajući, to nije više onaj isti joint od prije tridesetak godina, već puno jača droga, koja je u svakom slučaju vrlo rizična za konzumenta. S druge strane uporaba marihuane u medicinske svrhe, ${ }^{9}$ danas kao i u budućnosti, imat će mnogo prostora i primjene kao učinkovito terapijsko sredstvo.

\section{Zlouporaba}

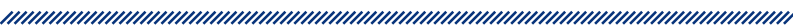

Zlouporaba ${ }^{10}$ marihuane kao droge veliko je i kompleksno područje, kako kroz njezinu proizvodnju i krijumčarenje tako i ilegalnu preprodaju. Zakonska definicija same zlouporabe određena je Zakonom o suzbijanju zlouporabe droga, ali isto tako važno ju je promatrati sa sociološkog, tradicionalnog i kulturološkog polazišta. Marihuana je droga, psihoaktivno sredstvo i kao takva nalazi se na Popisu droga, psihotropnih tvari i biljaka iz kojih se može dobiti droga te tvari koje se mogu uporabiti za izradu droga (na temelju članka 2. stavka 2. Zakona o suzbijanju zlouporabe droga, $\mathrm{Na}$ rodne novine br. 107/01, 87/02, 163/03, 141/04, 40/07, 149/09, 84/11, 80/13 i 13/19, ministar zdravstva donio

9 Terminološki nije ispravno uporabljivati u stručnoj i znanstvenoj komunikaciji izraz medicinska marihuana ili kanabis. Ispravan je izraz marihuana ili kanabis za medicinske svrhe odnosno uporabu.

10 ZLOPORABA, ZLOUPORABA ILI ZLOUPOTREBA DROGA lingvistički su u duhu hrvatskog jezika prihvaćeni termini, a u formalnoj komunikaciji češće se uporabljuje termin zlouporaba. Prema Zakonu o suzbijanju zlouporabe droga - ZLOUPORABA droge jest uzgoj biljke za dobivanje droge, posjedovanje sredstava za izradu te posjedovanje i promet droge i tvari koja se može uporabiti za izradu droge, protivno odredbama ovog Zakona. (čl. 15., NN 107/01, 87/02, 163/03, 141/04, 40/07, 149/09 (nema OPOJNO - čl. 12.), 84/11, 80/13, Zakon o izmjenama i dopunama Zakona o suzbijanju zlouporabe droga NN 39/19) - Direktiva (EU) 2017/2103 Europskog parlamenta i Vijeća od 15. studenoga 2017. u izmjeni Okvirne odluke Vijeća 2004/757/PUP kako bi se nove psihoaktivne tvari obuhvatile definicijom „droge”. Prema čl. 2. navedenog Zakona, pod UPORABOM se podrazumijeva jednokratno, višekratno, povremeno ili redovito uzimanje ili izlaganje djelovanju droge, a pod pojmom DROGE podrazumijeva se tvar koja je obuhvaćena Jedinstvenom konvencijom Ujedinjenih naroda o opojnim drogama iz 1961., kako je izmijenjena Protokolom iz 1972. ili Konvencijom Ujedinjenih naroda o psihotropnim tvarima iz 1971. i svaka tvar prirodnog ili umjetnoga podrijetla, uključivši psihotropne tvari uvrštene u Popis droga, psihotropnih tvari i biljaka iz kojih se može dobiti droga. je navedeni popis).

Važna činjenica od koje treba krenuti kad je u pitanju kriminal koji se veže uz zloporabu droga jest da čovjek čim je neovlašteno posegnuo za drogom ulazi u zonu kažnjavanja i kriminala. Promatra li se droga kao „ROBA" i njezina visoka cijena na ilegalnom tržištu, lako se može zaključiti da u svijetu nema nijedne robe koja postiže toliko veliku razliku u cijeni od zemlje proizvođača do zemlje potrošača kao što to postiže droga. Upravo je to i jedan od najvažnijih razloga što je danas u nedozvoljenoj trgovini i krijumčarenju, droga „ROBA BROJ 1". Godine 2017. neku vrstu droge trošilo je između 3,6 i $6,9 \%$ cjelokupne svjetske populacije u dobi od 15 do 64 godina, što je 167 do 315 milijuna (UNODC). ${ }^{11}$ Najviše trošena droga bila je marihuana, između 2,7 i 4,9 \%, što je brojčano iskazano 125 do 227 milijuna. Zapljene produkata na svjetskoj razini bile su u 2017. 6260 tona marihuane, a hašiša 1500 tona.

Biljni kanabis (marihuana) i smola kanabisa (hašiš) dva su glavna proizvoda od kanabisa koji se mogu pronaći na europskom tržištu droga. Ulje kanabisa relativno se rijetko može pronaći, iako je posljednjih godina zabilježeno nekoliko velikih zapljena. Marihuana koja se konzumira u Europi većinom se uzgaja u zemljama Europe (unutarnje sadnje i uzgoj), no određena se količina krijumčari i izvan europskih zemalja.

Hašiš se uglavnom uvozi iz Maroka, a Libija postaje glavno središte za krijumčarenje hašiša. Sve se češće bilježe slučajevi proizvodnje određene količine smole (hašiša) u Europskoj uniji, a u Nizozemskoj se već dugi niz godina bilježe slučajevi proizvodnje nizozemskog hašiša (tzv. nederhash). Tijekom 2017. u državama članicama EU-a zabilježeno je 782000 zapljena proizvoda od kanabisa, uključujući 440000 zapljena marihuane, a količine zapljena kanabisa u 2017. na području EU-a bile su 884 tone, od toga 304 tone marihuane. Cijene marihuane na ilegalnim tržištima u EU-u, kreću se između 12 i 25 eura po gramu (EMCDDA). ${ }^{12}$ Procjenjuje se da je u EU-u otprilike 96 milijuna ili $29 \%$ odraslih osoba u dobi od 15 do 64 godina, bilo u potrošnji kanabisa, najviše marihuane. Osim toga, zemlje zapadnog Balkana izvor su marihuane te posljednjih godina i ulja kanabisa.

Zlouporaba droga u Hrvatskoj sa svim obilježjima u smislu ponude i potražnje datira iz sedamdesetih go-

11 UNODC - United Nations Office on Drugs and Crime - Ured za suzbijanje droge i kriminala UN-a, World Drug Report 2017.

12 EMCDDA - European Monitoring Centre for Drugs and Drug Addiction - Europski Centar za praćenje droga i ovisnosti o drogama, European Drug Report 2019. 
dina prošlog stoljeća. Današnji trendovi zlouporabe dio su globalnih trendova u EU-u i svjetske narkoscene. Prema podacima Registra koji se vodi pri Hrvatskom zavodu za javno zdravstvo, godišnji broj liječenih ovisnika kreće se između sedam i osam tisuća. Registar liječenih ovisnika o drogama pri HZJZ-u prikuplja podatke od 1978. godine. Tijekom 2017. godine 925 osoba bilo je na liječenju od ovisnosti o kanabisu (13,1 \% ukupnog broja liječenih), što je za 171 osobu više nego 2016. godine. Operativne su procjene stručnjaka koji se bave suzbijanjem zlouporabe droga da u Hrvatskoj godišnje 30 do 40 tisuća osoba na neki način zlouporabljuje drogu, kroz potrošnju i ponudu, a najprisutnija je marihuana.

Kriminalne aktivnosti povezane sa zlouporabom droga na području Hrvatske uglavnom se svode na krijumčarenje i preprodaju, a manjim dijelom na proizvodnju. No sve se češće Hrvatski državljani pojavljuju kao akteri u organiziranom krijumčarenju na međunarodnoj sceni. Nezakonita proizvodnja prisutna je u smislu nezakonite sadnje i proizvodnje marihuane (najčešće unutarnjih sadnji, u zatvorenim prostorima). Sadnja na vanjskim zemljišnim parcelama rizičnija je za počinitelje zbog veće mogućnosti da bude otkrivena. Unutarnje (engl. indoor) sadnje i proizvodnja marihuane sve su prisutniji oblik. Drugačija je i tehnika sadnje, odnosno uzgoja, oprema i sredstva za uzgoj. Marihuana koja se dobije takvom proizvodnjom znatno je jača od one uzgojene na otvorenom. Primjerice, u jednom od prošle godine otkrivenih slučajeva unutarnje sadnje (plastenik) indijske konoplje u okolici Zagreba, trojica počinitelja samo su u opremu za uzgoj uložila trideset tisuća kuna (lampe, ventilatori, sustav navodnjavanja, zemlja - hidroponska sadnja, gnojivo). Kriminalističkim istraživanjem utvrđeno je da su u prethodnoj sadnji djelomično uspjeli proizvesti 50 kilograma marihuane. Koncentracija THC-a u zaplijenjenoj marihuani bila je visokih $20 \%$, dok je u tristotinjak biljki koje su uništene u stadiju rasta koncentracija THC-a bila $11 \%$.

Krijumčarenje marihuane u područje Hrvatske i kroz Hrvatsku u smislu tranzita posljednje je dvije godine sve prisutnije. Kriminalne grupe i organizacije proizvode marihuanu, poglavito na području Albanije i šire u regiji. Isto tako, aktivna je i balkanska ruta, sa svim svojim pravcima, a dominantno se krijumčare upravo marihuana i hašiš, premda tim pravcima dolaze i druge vrste droga (heroin, kokain, sintetičke droge). Krijumčari se na razne načine, od skrivenih prostora (bunkera) u prijevoznim sredstvima, prtljazi, zrakoplovima, brodovima, ovisno i o vrsti droge. Marihuana se najčešće ilegalno prenosi u osobnim i teretnim vozilima te plovilima morskim putem. Od 2013. godine raste broj pronalazaka paketa s biljnim kanabisom na hrvatskoj obali i jadranskim otocima, što je posljedica pojačanog krijumčarenja marihuane iz Albanije u Italiju morskim putem. Razlozi su odbacivanja marihuane u more višeslojni: od pojačanog djelovanja nacionalnih agencija država koje nadziru more na Mediteranu i Jadransku uzrokovanog migrantskom krizom, do vremenskih neprilika i havarija na moru. Bez obzira na akcije policija na izvorištima ilegalne proizvodnje marihuane (primjerice 2015. godine akcija albanske policije na suzbijanju ilegalne proizvodnje marihuane i one s jakom koncentracijom THC-a poznate u žargonu po nazivom skunk oko sela Lazarat u Albaniji, kada je znatno razbijena proizvodnja i zaplijenjeno je više stotina kilograma marihuane), proizvodnja i krijumčarenje nastavljaju se rastućim intenzitetom, iz smjera istočnih država prema Hrvatskoj i preko nje dalje u EU. U „balkanski kartel” krijumčara droge i drugih oblika transnacionalnoga organiziranog zločina (koji čine skupine kriminalaca sa šireg područja jugoistočnog Balkana) uključeni su i kriminalci s hrvatskim državljanstvom. Tako se pojavljuju različiti profili krijumčara. Dojučerašnji krijumčari duhana sada će krijumčariti unosniju robu drogu, a to je marihuana, iako je zakonski krijumčarenje droge kažnjivije (uz druge vrste droga, lako će se uključiti i u krijumčarenje ljudi), zbog zarade će im biti svakako prihvatljivija od duhana ili nekih drugih roba.

Prema podacima MUP-a RH (Statistički pregled temeljnih pokazatelja i rezultata rada u 2018.) godišnje se prijavi više od 13000 zakonski kažnjivih djela povezanih sa zlouporabom droga Kaznenih djela 2018. godine bilo je 2589 - 1094 počinitelja, a 11220 prekršaja, i to prema Zakonu o suzbijanju zlouporabe droga, Zakonu o prekršajima protiv javnog reda i mira te Zakonu o sigurnosti prometa. Ako se ima u vidu i tamna brojka (na jedno otkriveno djelo dolazi najmanje još jedno koje nikada neće biti otkriveno, razjašnjeno, procesuirano i presuđeno), onda je taj broj znatno veći. Važno je ovdje naglasiti i podatak kako su 2018. godine, prema podacima MUP-a, prijavljena 33 kaznena djela povezana sa zlouporabom droga počinjena u sastavu zločinačke organizacije, dok su 2017. prijavljena dva kaznena djela, što bi u postotku gledano bio porast za $1550 \%$. Ukupne zapljene droge, prema podacima MUP-a RH, 2018. godine bile su 4,8 tona (najviše marihuane, kokaina, ecstasyja).

Analizom opisanih podataka povezanih sa zlouporabom vidljivo je kako je marihuana kontinuirano najprisutnija. Uz ostvarivanje zarade kroz ilegalnu proi- 


\begin{tabular}{|c|c|c|c|c|c|c|c|}
\hline \multirow{3}{*}{ Kaznena djela } & \multicolumn{2}{|c|}{ Prijavljena } & & \multicolumn{2}{|c|}{ Razriješena } & \multirow{3}{*}{$+-\%$} & \multirow{3}{*}{$\begin{array}{c}2018 . \% \\
\text { ukupno } \\
\text { prijavljenih }\end{array}$} \\
\hline & \multicolumn{2}{|c|}{ Broj djela } & \multirow{2}{*}{$+-\%$} & \multicolumn{2}{|c|}{ Broj djela } & & \\
\hline & 2017. & 2018. & & 2017. & 2018. & & \\
\hline $\begin{array}{c}\text { Neovlaštena proizvodnja i } \\
\text { promet droga }\end{array}$ & 2093 & 1880 & $-10,2$ & 2088 & 1878 & $-10,1$ & 82,7 \\
\hline $\begin{array}{c}\text { Omogućavanje trošenja } \\
\text { droga }\end{array}$ & 491 & 388 & $-21,0$ & 491 & 388 & $-21,0$ & 17,1 \\
\hline $\begin{array}{l}\text { Neovlaštena proizvodnja i } \\
\text { promet tvari zabranjenih u } \\
\text { sportu }\end{array}$ & 5 & 6 & $+20,0$ & 5 & 6 & $+20,0$ & 0,3 \\
\hline UKUPNO & 2589 & 2274 & $-12,2$ & 2584 & 2272 & $-12,1$ & 100,0 \\
\hline
\end{tabular}

\begin{tabular}{|c|c|c|c|}
\hline \multirow{2}{*}{ Vrsta droga } & \multicolumn{3}{|c|}{ Količina zaplijenjene droge } \\
\hline & 2017. & 2018. & $+-\%$ \\
\hline Heroin (g) & 26895,99 & 5588,37 & $-79,2$ \\
\hline Hašiš (g) & 8600,17 & 50338,23 & $+485,3$ \\
\hline Marihuana (g) & 2855858,94 & 4752886,13 & $+66,4$ \\
\hline Kokain (g) & 483855,40 & 109636,20 & $-77,3$ \\
\hline Amfetamini (g) & 38227,61 & 34222,44 & $-10,5$ \\
\hline Metadoni (tb.) & 1011,00 & 498,00 & $-50,7$ \\
\hline Ecstasy (g) & 13039,04 & 13093,29 & $+0,4$ \\
\hline LSD (doza) & 977,00 & 369,00 & $-62,2$ \\
\hline
\end{tabular}

zvodnju, krijumčarenje i prodaju, tu su prisutne i druge situacije koje pridonose širenju zlouporabe. Važan je čimbenik u suzbijanju represija, no ako nema prevencije, željeni pozitivni pomaci ne mogu se očekivati. Liberalniji stavovi prema posjedovanju količina droge za osobnu uporabu (poglavito marihuane), gdje okolnosti ukazuju da nije prisutna namjera daljnje preprodaje, imaju svoj smisao kao učinkovita reakcija zakonodavca. Pravilno medijsko informiranje o zlouporabi isto tako ima važan preventivni učinak. Izmjenama Kaznenog zakona RH 2012. godine posjedovanje droge u manjoj količini gdje okolnosti ukazuju da nema namjere daljnje preprodaje i takva kažnjiva djela prebačena su u zonu prekršajne odgovornosti (s tim u svezi upotrebljava se pojam dekriminalizacije, iako bi to moglo biti predmetom stručnog razmatranja pravne struke). Naime, količina ne mora biti presudna, jer ako, primjerice, netko $\mathrm{s}$ jednim jointom marihuane omogući trošenje drugoj osobi, ulazi u zonu kaznenopravne odgovornosti. Sad- nja indijske konoplje, odnosno proizvodnja, ostala je i dalje kazneno djelo, bez obzira na broj zasađenih biljki. (Suautor ovog materijala bio je član radne skupine koja je bila zadužena za navedene izmjene te je predložio da sadnja dvije stabljike biljke bude prekršajno djelo, međutim radna se skupina s tim nije složila. Današnji zakonski pristupi u 15-ak država EU-a smatraju zakonitom sadnju indijske konoplje za osobne medicinske potrebe.) Neovlaštena sadnja indijske konoplje kazneno je djelo, ${ }^{13}$ a kakav će stav prema počinitelju u pojedinim slučajevima zauzeti pravosudni sustav ovisit će o slučaju i shvaćanju ispričavajućih okolnosti prema počinitelju (namjera sadnje radi osobne konzumacije kao lijeka). Dosadašnja sudska praksa pokazala je uvažavanja reče-

13 U Zakonu o suzbijanju zlouporabe droga definirana je neovlaštena sadnja, uzgoj i biljka (čl. 2.), dok je kao kazneno djelo u KZ-u RH inkriminirana u čl. 190. st. 1. i 2. - Neovlaštena proizvodnja i promet drogama. 
nih okolnosti u donošenju oslobađajućih pravorijeka prema počiniteljima koji su radi zdravstvenih problema zasadili i trošili marihuanu kao terapijsko sredstvo. Bez obzira na tu činjenicu, sadnja i proizvodnja marihuane ne podrazumijeva samoinicijativni uzgoj, već je za to potrebno imati dozvolu u skladu s pozitivnim zakonskim propisima (više o proizvodnji i sadnji u poglavlju o medicinskoj uporabi).

Analizirajući ponudu i potražnju kao dva osnovna elementa zlouporabe, treba naglasiti kako učinkovita kaznena politika, uz ostale aktivnosti, ima znatan utjecaj na smanjenje ponude droga, ali i utjecaj na prevenciju zlouporabe droga. U tom smislu važan je cilj upravo spriječiti da povremeno konzumiranje droga preraste $u$ ovisnost. Uz strože kažnjavanje organizatora mreže preprodavatelja droga i proširenje asortimana radnji počinjenja zlouporabe droga, od ključne je važnosti i uključivanje u sustav tretmana počinitelja kaznenih djela povezanih s drogama koji su ujedno ovisnici. Praksa je pokazala da sankcija, iako nužna te ima svoj generalni i specijalni učinak prema počiniteljima i onim potencijalnima, nije jedini ključ rješenja problema. Također je učinkovito i potrebno izricanje obvezujućih mjera (osim zatvorenog tipa u sklopu zatvorskog sustava, tu su savjetovališta, centri za prevenciju i liječenje, nevladine udruge), jer tretman predstavlja najbolju alternativu za prekidanje eksperimentiranja s drogama i recidivizam. Razvoj kaznene politike i zakonodavstva, uz praćenje situacije na nacionalnoj sceni u svezi sa zlouporabom, treba temeljiti na preporukama i odlukama tijela Europske unije te ih kontinuirano usklađivati s pravnom stečevinom Europske unije.

Pozitivno hrvatsko kazneno i prekršajno zakonodavstvo na području suzbijanja zlouporabe droga temelji se na nekoliko zakonskih propisa:

Zakon o suzbijanju zlouporabe droga (NN 125/11, $144 / 12,56 / 15,61 / 15,101 / 17,118 / 18,39 / 19)$, Kazneni zakon (NN 125/11, 144/12, 56/15, 61/15, 101/17, 118/18, na snazi od 4. siječnja 2019.), Zakon o kaznenom postupku (NN 152/08, 76/09, 80/11, 121/11, 91/12, 143/12, 56/13, $145 / 13,152 / 14,70 / 17$, na snazi od 27. srpnja 2017.), Zakon o sudovima za mladež (NN 84/11, 143/12, 148/13, 56/15, na snazi od 30. svibnja 2015.), Prekršajni zakon (NN 107/07, 39/13, 157/13, 110/15, 70/17, 118/18, na snazi od 1. siječnja 2019.), Zakon o sigurnosti prometa na cestama (NN 67/08, 48/10, 74/11, 80/13, 158/13, 92/14, 64/15, 108/17, na snazi od 16. studenoga 2017.).

\section{Medicinska uporaba}

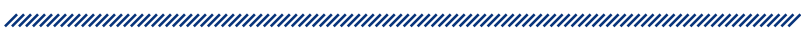

Pojmovno značenje riječi droga kakvo nalazimo u Medicinskoj enciklopediji (Leksikografski zavod, Zagreb, 1958.): „kao sirovi, napola prerađeni i sušeni proizvodi biljnog, životinjskog ili mineralnog podrijetla koji služe za izradu lijekova (ljekovite droge) i kao mirodije u tehničke svrhe (tehničke droge)", iako je staro više od šezdeset godina, do današnjih dana nije izgubilo svoje značenje kad se govori o medicinskoj uporabi. Tehnološki napredak, lakše stjecanje spoznaja o strukturi i istraživanje donijeli su mogućnosti da se iz biljnih produkata izdvoje različite supstancije koje su po svojem sastavu znatno jače i s većom koncentracijom aktivne tvari nego što je to izvorno u biljkama. Također, važna je okolnost sintetička proizvodnja, koja je zanemarila prirodnu osnovu i donijela gotovo teško zamjenjivu mogućnost u odnosu na primjenu prirodnih tvari. Jedan je aspekt rečene proizvodnje koji se u tom kontekstu nastoji izbjeći zarada farmaceutske industrije, „, jakog lobija" koji danas u svijetu ostvaruje goleme profite. Povratak prirodnim resursima odnosno tvarima nije nemoguć, ali da bi u pojedinim situacijama do toga došlo, uvijek treba proći dosta vremena uz velik broj kliničkih i drugih istraživanja. Istraživanja su skupa i zahtjevna i često ih financiraju upravo moćne farmaceutske tvrtke i korporacije. Ova konstatacija nije tendenciozna i kritički postavljena prema tome, jer je to nužno, opravdano i korisno. No uvijek će se otvarati niz pitanja na koje će odgovori i objašnjenja biti diskutabilni u javnosti, bez obzira na znanstveno prikazane rezultate.

Znanstvena ispitivanja posljednjih godina (ali i više desetljeća) donijela su drugačiji pristup prema medicinskoj uporabi marihuane. Klinička ispitivanja, iako nisu prihvaćena generalno u svijetu, otvorila su marihuani i tvarima koje sadrži (poglavito kanabinoidima), mogućnosti kao terapijskom sredstvu za razne bolesti. U prilog tome išla su iskustva bolesnika koji su posegnuli za marihuanom kao prirodnim lijekom kad im konvencionalni lijekovi nisu pomogli.

lako su takva iskustva u Hrvatskoj već duže prisutna, nisu imala zakonska, lege artis uporišta od medicinske struke. Takav stav struke i zakonodavca imao je za rezultat poticanje ilegalne proizvodnje THC-a u obliku ulja i kapi, koji su se „na crno” nabavljali od ilegalnih proizvođača. Pripravci pribavljani na ovakav nezakonit način, sumnjivog kvalitativnog i kvantitativnog sadrža- 
ja, bili su rizični i skupi za korisnike, a njihova ljekovita učinkovitost bila je upitna. Slijedom svih navedenih trendova, Ministarstvo zdravstva RH odlučilo je 2014. godine formirati stručno Povjerenstvo za analizu i preporuke primjene indijske konoplje/kanabinoida u medicinske svrhe.

Nakon analize i razmatranja Povjerenstvo je donijelo zaključke o mogućnostima medicinske primjene te je nakon toga donesenim Pravilnikom omogućeno legalno propisivanje lijeka koji sadrži THC. ${ }^{14}$

Budući da je otvorena zakonska mogućnost propisivanja odnosno nabavljanja lijeka, jedina mogućnost bila je kupovina izvan granica Hrvatske, odnosno ovlašteni dobavljači 2016. godine uvezli su određenu količinu iz Kanade. (Uvezeno je 10000 kapsula ekstrakta kanabisa jačine 2,5 mg THC-a i 2,5 mg CBD-a te 10000 kapsula jačine $5 \mathrm{mg}$ THC-a i 5 mg CBD-a. Manji dio tih kapsula prodan je pacijentima, no s obzirom na to da su kapsule tehnički bile izrađene za suho punjenje, procurio je sadržaj i ostatak je kapsula povučen iz prodaje.) Farmaceutske tvrtke u Hrvatskoj nisu proizvodile (u vrijeme pisanja ovog materijala još uvijek to nije praksa) tu vrstu lijeka, a uvozni je svojom cijenom preskup za većinu pacijenata (HZZO nije stavio na popis lijekova koje bi financijski pokrivao). U međuvremenu su stupile na snagu izmjene Zakona o suzbijanju zlouporabe droga, kojima je, uz ostale izmjene, predviđena proizvodnja indijske konoplje u medicinske svrhe. ${ }^{15}$ Ministar zdravstva tijekom ove godine donijet će u vezi s proizvodnjom u medicinske svrhe prateći pravilnik, kojim će se regulirati dozvole, uzgoj, način, sjeme, otkup i drugi tehnički detalji.

Vidljivo je da će konoplju u medicinske svrhe moći uzgajati oni pravni subjekti koji proizvode lijekove. Na taj će se način omogućiti i snižavanje cijena lijekova kojima je sirovina indijska konoplja. Ostaje otvoreno pitanje hoće li farmaceutske tvrtke u Hrvatskoj naći interes za proizvodnju, odnosno hoće li biti zainteresiranih (legalnih, jer onih ilegalnih uvijek ima) uzgajivača indijske kono-

14 Pravilnik o mjerilima za razvrstavanje lijekova te o propisivanju i izdavanju lijekova na recept, NN 86/13, 90/13, 102/14, 107/15, 72/16, čl. 30.a - Lijekovi koji sadrže THC, dronabinol i nabilon mogu se propisivati za ublažavanje tegoba kod multiple skleroze, karcinoma, epilepsije i AIDS-a.

15 Zakon o suzbijanju zlouporabe droga, NN 107/01, 87/02, 163/03, $141 / 04,40 / 07,149 / 09,84 / 11,80 / 13,39 / 19$, na snazi od 25 . travnja 2019., čl. 15. - Drogu mogu izrađivati samo pravne osobe koje za obavljanje te djelatnosti udovoljavaju uvjetima propisanim za pravne osobe koje proizvode lijekove i imaju odobrenje Agencije za lijekove i medicinske proizvode, odnosno veterinarsko-medicinske proizvode i koje imaju odobrenje ministarstva nadležnog za poljoprivredu, u skladu s posebnim propisima. plje koji bi u tome našli svoj financijski interes. Sigurno je da će se time djelomično suzbiti ilegalna proizvodnja, međutim ako se ima u vidu državni nadzor kojim će se odrediti i određena porezna davanja, dozvole i takse, bit će onih koji će to izbjegavati, proizvodeći i preprodavajući „na crno” marihuanu i pripravke mimo državnog nadzora (primjerice, poput proizvodnje i ilegalne prodaje duhana, što je posljednjih godina aktualno na području Hrvatske, a također krijumčarenje duhanskih proizvoda iz država u okruženju gdje ti proizvodi imaju nižu cijenu). Nerijetko se na ilegalnom tržištu pojavljuju i različiti medicinski proizvodi, krivotvorine ili nezakonito proizvedeni, koji svojom nižom cijenom privlače potencijalne kupce. Problemi zasićenja tržišta mogu se dogoditi i kod legalne proizvodnje. Logično je za očekivati da će biti dosta onih koji će u zakonitoj proizvodnji i prodaji potražiti zaradu. $U$ početku će to sigurno biti isplativo, no trebat će imati u vidu potrebe tržišta, ne samo u Hrvatskoj nego i globalno na međunarodnom planu. (U SAD-u, u saveznoj državni Oregon, gdje je 2016. legalizirana rekreativna uporaba, proizvođači su suočeni s tim problemom.)

Bez obzira na sve spomenute okolnosti, pozitivno je i korisno da će se u Hrvatskoj pacijentima kojima je to potrebno zakonski omogućiti nabavljanje lijekova na bazi indijske konoplje. Za sad je to predviđeno za samo nekoliko bolesti, ali opravdano je za očekivati da će se taj broj nakon daljnjih istraživanja povećati.

Što se tiče same medicinske uporabe kao terapijskog sredstva, primjerice za jednu od bolesti, u posljednjih je desetak godina u svijetu provedeno dosta kliničkih studija koje su ispitivale djelovanje indijske konoplje na simptome multiple skleroze ${ }^{16}$ (spasticitet, središnja bol i bolni spazmi, tremor i narušena funkcija mokraćnog mjehura). Povjerenstvo ${ }^{17}$ za analizu i preporuke primjene indijske konoplje / kanabinoida u medicinske svrhe nakon opsežnih analiza dalo je zaključke koji se odnose na indijsku konoplju kao terapijsko sredstvo. Između ostalog je zaključeno:

- Ni za jedan pripravak čiji se terapijski princip temelji na aktivaciji kanabinoidnih receptora, „industrijski” ili „magistralni”, sintetski analog

16 Multipla skleroza - MS jest kronična, upalna, demijelinizacijska bolest središnjega živčanog sustava kod koje je mijelinski omotač, supstancija koja oblaže živčana vlakna, oštećen. lako je MS davno otkrivena, još uvijek nije otkriven lijek niti je poznat pravi uzrok bolesti. MSD - Priručnik dijagnostike i terapije.

17 Detaljan opis načina primjene opisao je u dokumentu koji je bio dio zaključaka rada Povjerenstva prof. dr. sc. Vladimir Trkulja, koji je, kao i suautori ovog rada, član Povjerenstva. 
ili „ekstrakt kanabisa”, nije pokazano da je sposoban zaliječiti ili trajno izliječiti malignu bolest.

- Sve preporuke odnose se samo na striktno navedene indikacije, pa se preporučeni pripravci ne preporučuju primjenjivati kod drugih bolesti koje uzrokuju kaheksiju/anoreksiju, spasticitet ili umjerenu do srednje tešku bol.

- Preporučeni pripravci pridodaju se drugim medicinskim indiciranim intervencijama/lijekovima kao add-on terapija te se ne preporučuje ukidanje drugih oblika liječenja kod uvođenje preporučenih pripravaka.

Popis indikacija za koje je napravljena analiza objavljenih znanstvenih radova o djelovanju kanabinoida/ kanabisa:

\section{1) Multipla skleroza}

Ni za jedan pripravak čiji se terapijski princip temelji na aktivaciji kanabinoidnih receptora, ,industrijski” ili „magistralni”, sintetski analog ili „ekstrakt kanabisa”, nije pokazano da utječe na progresiju MS-a ni u kliničkom ni u morfološkom smislu (broj i dinamika lezija). Međutim, za neke je pripravke pokazano da ublažavaju neke od simptoma MS-a. Povjerenstvo je stava da se za indikaciju „simptomatsko ublažavanje spasticiteta u bolesnika koji boluju od multiple skleroze kojima spasticitet nije adekvatno kontroliran konvencionalnom terapijom" pripravak kanabisa može preporučiti kao terapijska opcija.

\section{2) Maligne bolesti}

Ni za jedan pripravak čiji se terapijski princip temelji na aktivaciji kanabinoidnih receptora nije pokazano da utječe na progresiju maligne bolesti. Međutim, za neke je pripravke pokazano da ublažavaju neke od simptoma malignih bolesti. Povjerenstvo je stava da se za indikaciju „u bolesnika s uz napredovalom/terminalnom malignom bolešću i kroničnom umjerenom do srednje teškom boli” može preporučiti pripravak kanabisa, kao i za indikaciju „ublažavanje mučnine i povraćanja u bolesnika s malignim bolestima koji primaju emetogenu terapiju (antitumorski lijekovi, zračenje)".

\section{3) HIV/AIDS}

Ni za jedan pripravak čiji se terapijski princip temelji na aktivaciji kanabinoidnih receptora nije pokazano da utječe na progresiju AIDS-a ili infekciju HIV-om. Međutim, za neke je pripravke pokazano da ublažavaju neke od simptoma AIDS-a. Povjerenstvo je stava da se za indikaciju „u liječenju kaheksije/anoreksije u HIV/AIDS bolesnika" može preporučiti pripravak kanabisa.
4) Ostala neurološka oboljenje (osim MS-a)

Ni za jedan pripravak čiji se terapijski princip temelji na aktivaciji kanabinoidnih receptora nije jasno pokazano da utječe na progresiju ili smanjenje simptoma koreje u Huntingtonovoj bolesti, cervikalnoj distoniji, Touretteovu sindromu, levodopom inducirane diskinezije u Parkinsonovoj bolesti te konvulzivnim stanjima - epilepsiji - poremećajima pokreta. Povjerenstvo je zauzelo stav da se u spomenutim bolestima ne može preporučiti pripravak kanabisa.

Povjerenstvo je upoznato $s$ registracijom lijeka Epidiolex (GW Pharamceuticals) koji je sastavom ekstrakt kanabisa s 98-postotnim udjelom CBD-a (kanabidiol). Registracijom novog lijeka Epidiolex (GW Pharmaceuticals) za liječenje Dravetova sindroma (dječjega epileptičkog sindroma) Europska agencija za lijekove prihvatila je „kanabidiolski CBD princip”. Povjerenstvo je zauzelo stav da se u opisanoj indikaciji može preporučiti pripravak kanabisa ako spomenuti lijek ne bude dostupan u RH.

\section{5) Psihijatrijski poremećaji}

$\mathrm{Ni}$ za jedan pripravak čiji se terapijski princip temelji na aktivaciji kanabinoidnih receptora nije pokazano da utječe na progresiju ili ublažavanje simptoma psihoza, psihotičnih stanja, shizofrenije te anksioznih poremećaja, depresivnih poremećaja ili PTSP-a. Povjerenstvo je zauzelo stav da se u spomenutim bolestima ne može preporučiti pripravak kanabisa.

Također, Povjerenstvo je zaključilo kako je u daljnjem radu potrebno:

- kontinuirano detaljno praćenje i analiza odgovarajućih mehanizama kontrole u sprječavanju možebitne zlouporabe

- analiza mogućnosti terapije za nove indikacije (neuropatska bol, kronična bol izvan malignih oboljenja, poremećaj sna, Touretteov sindrom)

- edukacija ljekarnika i liječnika o načinu pisanja recepta, indikacijama te objedinjenje načina primjene kanabisa i njegovih ekstrakata u medicinskim sustavima drugih zemalja

- ex juvantibus terapija - korisnici koji imaju pozitivna iskustva (malignomi i druge indikacije).

$\mathrm{Na}$ temelju svega opisanog, vidljivo je kako u kontekstu medicinske uporabe indijska konoplja kao terapijsko sredstvo može imati važno mjesto. Takav pristup podr- 
žao je i Međunarodni odbor za kontrolu droga (INCB) ${ }^{18}$ na godišnjem zasjedanju 2012. godine kada su donesene važne informacije o uporabi kanabisa u medicinske ili znanstvene svrhe za donositelje odluka kako bi se udovoljilo obveznim mjerama kontrole. S time u vezi INCB podržava znanstvena istraživanja o koristi kanabisa ili ekstrakata kanabisa u terapijske svrhe koja su provedena u nekoliko zemalja. Odbor izražava zabrinutost zbog činjenice da je nekoliko vlada odobrilo uporabu kanabisa u medicinske svrhe bez odgovarajućih znanstvenih potvrda o njezinoj učinkovitosti. Kako se navodi u Izvješću, na temelju članka 28. Konvencije iz 1961., država koja dopušta uzgoj kanabisa za proizvodnju kanabisa mora uspostaviti Nacionalnu agenciju za kanabis za obavljanje djelatnosti propisane člankom 23. Konvencije. Agencija označava područja u kojima je dopušten uzgoj, licencije uzgajivača i kupnju, uzima u fizički posjed usjev te ima isključivo pravo veleprodaje i održavanje zaliha. Kao i za sve opojne droge, stranke Konvencije imaju obvezu dostaviti Odboru svake godine svoje procjene i statistička izvješća u svezi s kanabisom. INCB moli sve zabrinute vlade da osiguraju poštivanje mjera kontrole za kanabis u skladu s Konvencijom iz 1961. godine.

Prilikom izmjene zakona i donošenja odluka Hrvatska je uzela u obzir preporuke INCB-a, a isto tako Povjerenstvo o kojem je bilo riječi kao stručno tijelo pratit će i analizirati situaciju, trendove i promjene kako na domaćem tako i međunarodnom planu. Na kraju, kad je u pitanju medicinska uporaba indijske konoplje, može se reći kako do sada kliničke studije nisu potvrdile utjecaj na trajno izlječenje ili progresiju bolesti o kojima je bilo govora, ali svakako da može olakšati postojeće stanje pacijentima. Što će buduća ispitivanja pokazati, teško je reći, ali već su dosadašnji napredci znatni pomaci za medicinsku struku.
18 INCB - International Narcotic Control Bord - Međunarodni odbor za kontrolu droga - neovisno međunarodno tijelo osnovano pri UN-u 1968. godine na temelju Jedinstvene konvencije o drogama iz 1961.

\section{Zaključna razmatranja}

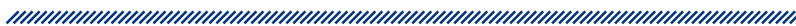

Praktična iskustva i spoznaje iz prošlosti ne smiju se zaboravljati ni onda kad tehnološki napredak donosi nove znanstvene i empirijske mogućnosti gotovo u svim područjima funkcioniranja društva. Takav je slučaj i s uporabom konoplje, bila riječ o uporabi ili zlouporabi. Botanički gledano, ta strukturom i sastavom kompleksna biljka ima svoje mjesto s velikom primjenom u komercijalne svrhe, ali s dominantnom podvrstom Cannabis indica pojavljuje se u zlouporabi, kao i u medicinskoj uporabi. Kao psihoaktivno sredstvo - droga, marihuana je najrasprostranjeniji tip droge kako u potrošnji tako i ilegalnoj proizvodnji, krijumčarenju i preprodaji. Potražnja i potrošnja važan su čimbenik koji diktira zakonske i druge pristupe $u$ današnjim trendovima prema indijskoj konoplji odnosno marihuani. Bez obzira na sve međunarodne inicijative, aktivnosti međunarodnih tijela i organizacija, prvenstveno kroz donošenje konvencija, odluka i direktiva, te nacionalne zakonodavne okvire globalno gledajući nije moguće značajno uskladiti. Kad je riječ o zlouporabi, treba uz potražnju imati u vidu kriminalno djelovanje, kojim se ostvaruju veliki ilegalni financijski profiti, zarade od proizvodnje, krijumčarenja i preprodaje. Aktivnosti represivnoga državnog sustava prema pojedincima, skupinama, kartelima i organizacijama, kao čimbenicima transnacionalnog organiziranog kriminaliteta, gdje su droge sastavni dio, moraju biti temeljene na praćenju stanja i trendova te planiranoj, dobro osmišljenoj i kontinuiranoj međunarodnoj suradnji.

Konvencionalni načini liječenja legitiman su medicinski pristup terapiji i ublažavanju tegoba pacijentima za sve bolesti. Indijska konoplja s glavnim sastojcima kanabinoidima, THC-om i CBD-om, poznata je čovjeku kao lijek još od daleke prošlosti i ima svoj kontinuitet. Taj kontinuitet imao je različite stadije, kao i legitimnost kako su društvo i medicina prihvaćali indijsku konoplju kao lijek. Nove spoznaje o njezinu sastavu i kliničke studije omogućile su širu medicinsku primjenu. Dosadašnja istraživanja i prihvaćene kliničke studije u Hrvatskoj omogućile su zakonitu medicinsku primjenu za ublažavanje tegoba kod multiple skleroze, karcinoma, epilepsije i AIDS-a. Sadnja i proizvodnja u medicinske svrhe, izmjenama zakona, dale su pravnim osobama nove mogućnosti za gospodarske djelatnosti, ali i niže cijene pacijentima, koji za takvu terapiju moraju skupo plaćati. 
Na kraju ostaje otvoreno zakonsko, etičko i moralno pitanje koje često postavljaju pacijenti koji boluju od navedenih bolesti, a indijska konoplja - marihuana pomaže im kao lijek. To pitanje odnosi se na osobnu sadnju radi zdravstvenih tegoba, znači u medicinske svrhe. Logično je i zakonski odgovorno da na takve upite nadležna državna tijela, u sladu sa zakonom, moraju dati negativne odgovore, a pacijenti, poštujući zakon, bez obzira na prisutnu bolest, ne zasađuju indijsku konoplju. S druge strane, takve se nezakonite sadnje događaju, a pojedinci koji u sudskom postupku dokazuju kako im je marihuana potrebna i nužna kao lijek zbog bolesti bivaju oslobođeni od kaznene odgovornosti. Takav postupak mnogima ostaje nejasan. Takve jednostavno rečeno nelogične i društveno upitne, a zakonski neprihvatljive situacije u budućnosti će možda biti riješene drugačijim zakonskim pristupom, a inicijative su već prisutne na međunarodnom planu. Slijedom svega navedenog, potrebno je globalno pratiti praktične situacije, klinička i druga istraživanja te zakonske promjene, a onda slijedom njih donositi odgovarajuće društveno prihvatljive odluke i na nacionalnoj razini.

\section{Reference}

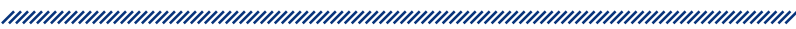

Prilikom izrade i pisanja ovog stručnog članka, osim literature navedene u nastavku, autori su se koristili osobnim saznanjima, analizama, informacijama te operativnim iskustvima iz dugogodišnje kriminalističke prakse na području suzbijanja zlouporabe droga, a također osobnim medicinskim stručnim, empirijskim i znanstvenim spoznajama, kako na domaćoj tako i međunarodnoj sceni.

1. Bortner MA. Delinquency and Justice, School of Justice Studies, Arizona State University, 1988.

2. Barry C, Dennis P. Marihuana. Zagreb: Celeber, 2004.

3. Davison CG, Neale JM. Psihologija abnormalnog ponašanja i doživljavanja, prijevod i hrvatska obrada, Jastrebarsko: Naklada Slap, 1999.

4. DEA: Drug information - International Threat Assessments, Washington D. C., 2018.

5. European Monitoring Centre for Drugs and Drugs Addiction: European Drug Report, Trends and Developments, Lisabon, 2018.

6. West R. EMCDDA INSIGHTS - Models of addiction, Lisabon, 2013.

7. Cannabinoids. Dostupno na: www.psychoactives.wikia. com (pristupljeno 1.8.2019.).

8. Jukić V. Psihijatrijske teme za ne psihijatre, Zagreb: Medicinska naklada, 2018.

9. Geber J, Bulat M, Lacković Z. Medicinska farmakologija, drugo izdanje, Zagreb: Medicinska naklada, 1999.

10. Gieringer D, Rosenthal E, Carter GT. Marijuana Medical Handbook - practical guide to the therapeutic uses of marijuana. Quick trading company, 2008.

11. Klarić D. Droga (NE)rješiv problem, Zagreb: Dvotočka, 2007.

12. Klarić D. Droga ovisnosti i nasilje, ZDS, 2017. $(65,87,92)$.

13. Kušević V. Zloupotreba droga, Zagreb: RSUP RH, 1990.

14. Kraljevska hrvatsko-slavonsko-dalmatinska zemaljska vlada, Hrvatsko-slavonski ljekopis, 1901.

15. Modly D, Šuperina M, Korajlić N. Rječnik kriminalistike, Zagreb: Strukovna udruga kriminalista, 2008.

16. Molecules, marijuana and CBD. Dostupno na: www.neurologycbd.com (pristupljeno 27.7.2019.).

17. Medicinska enciklopedija, Zagreb: Leksikografski zavod, 1958.

18. Pharmacology and effects of cannabis. Dostupno na: www.ukcia.org (pristupljeno 28.7.2019.).

19. Potter B, Joy D. The healing magic of cannabis. Oakland: Ronin publishing, 1998.

20. Šuperina Z. Rajski putevi pakla, Rijeka, 1979. $(14,15)$

21. Ured za suzbijanje zlouporabe droga: Godišnje izvješće o provedbi Nacionalne strategije suzbijanja zlouporabe droga 2018. godine 
22. Ways to consume marijuana. Dostupno na: www.unitedpatientsgroup.com (pristupljeno 27.7.2019.).

23. Godišnje izvješće o drogama, UNODC (United Nations Office on Drugs and Crime): Wold Drug Report 2018., Beč.

24. Europsko izvješće o drogama - trendovi i razvoj, EMCDDA, 2019.

25. NACIONALNA STRATEGIJA SUZBIJANJA ZLOUPORABE DROGA u RH (2012. - 2017.)

26. MUP RH. Statistički pregled temeljnih pokazatelja i rezultata rada u 2018. godini

27. Jandrić A, Doležal D i dr. Izvješće o projektu „Istraživanje tržišta droga u republici hrvatskoj - uloga sekundarnog kriminaliteta”, Zagreb, 2016.

\section{ZAKONI I PRAVILNICI:}

1. Kazneni zakon, NN 125/11, 144/12, 56/15, 61/15, 101/17, $118 / 18$.

2. Zakon o suzbijanju zlouporabe droga, NN 125/11, 144/12, 56/15, 61/15, 101/17, 118/18, 39/19.

3. Zakon o prekršajima protiv javnog reda i mira, NN 5/90, 30/90, 47/90, 29/94.

4. Prekršajni zakon, NN 107/07, 39/13, 157/13, 110/15, 70/17, 118/18.

5. Zakon o kaznenom postupku, NN 152/08, 76/09, 80/11, $121 / 11,91 / 12,143 / 12,56 / 13,145 / 13,152 / 14,70 / 17$.

6. Zakon o medicinskim proizvodima, NN 76/13.

7. Zakon o sjemenu, sadnom materijalu i priznavanju sorti poljoprivrednog bilja, NN 140/05, 35/08, 25/09, 124/10, 55/11.

8. Pravilnik o uvjetima za uzgoj konoplje, načinu prijave uzgoja maka te uvjetima za posjedovanje opojnih droga u veterinarstvu, NN 18/12.

9. Pravilnik o mjerilima za razvrstavanje lijekova te o propisivanju i izdavanju lijekova na recept, NN 86/13, 90/13, 102/14, 107/15, 72/16.

10. Popis, droga, psihotropnih tvari i biljaka iz kojih se može dobiti droga te tvari koje se mogu uporabiti za izradu droga, NN 156/14 - 22. prosinca 2014.

\section{OSTALI RELEVANTNI IZVORI}

Zaključci i izvješća sa sastanaka Povjerenstva za analizu i preporuke primjene indijske konoplje/kanabinoida u medicinske svrhe Ministarstva zdravstva RH (2015./2016.)

11. UN - Jedinstvena konvencija o opojnim drogama, New York, 1961.

12. UN - Konvencija o psihotropnim tvarima, Beč, 1972.

13. UN - Protokol o izmjenama jedinstvene konvencije o opojnim drogama, Ženeva, 1972.

14. UN - Konvencija UN-a protiv nedozvoljenog prometa drogama i psihotropnim supstancijama, Beč, 1988.

EMCDDA: Drugs and crime - a complex relationship, Lisabon. 2007.

EMCDDA: Drugs in focus, 2. izdanje, Lisabon, 2007., Briefing of the EMCDDA 


\section{MARIJUANA - ABUSE AND MEDICAL USE}

\section{Summary}

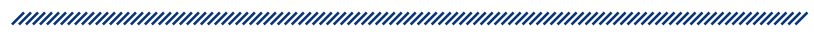

This paper elaborates the importance of the use and abuse of Indian hemp (Cannabis sativa L., subspecies Indian). Its recognized effects as a psychoactive agent (the major constituent is THC delta-9-tetrahydrocannabinol) have led to different forms of use, which also include its use as a medicine for medical purposes. Technological advances and related research have led to the discovery of a large number of other ingredients (CBD cannabidiol - cannabinoids) in Indian hemp which are not psychoactive, but have nevertheless found application in medical treatment. Marijuana today, though only as one product, has in daily communication become synonymous with Indian hemp. It is the most widely offered and sought after drug in illegal markets (hashish products, hashish oil, various blends and forms of Indian hemp products are not as widespread as marijuana). The boundary of use illegal will sometimes be difficult to determine, but certainly in this respect, a scientific and empirical multidisciplinary approach, understanding and decision-making are needed.

Keywords: marijuana, cannabis, abuse, medical use 